\title{
Polarized Cytokine Release Triggered by P2X7 Receptor from Retinal Pigmented Epithelial Cells Dependent on Calcium Influx
}

\author{
Xiaolei Shao ${ }^{1,2,+}$, Sonia Guha ${ }^{2,3,+}$, Wennan Lu ${ }^{4}$, Keith E. Campagno ${ }^{4}$, Jonathan M. Beckel ${ }^{2,5}$, \\ Jason A. Mills ${ }^{6,7}$, Wenli Yang ${ }^{8}$ and Claire H. Mitchell ${ }^{2,4,6,9, *}$ \\ 1 Shenzhen Eye Hospital, School of Optometry, Shenzhen University, Shenzhen 518060, China; \\ sx1320@hotmail.com \\ 2 Department of Anatomy and Cell Biology, University of Pennsylvania, Philadelphia, PA 19104, USA; \\ guha@jsei.ucla.edu (S.G.); JMBECKEL@pitt.edu (J.M.B.) \\ 3 Jules Stein Eye Institute, University of California Los Angeles, Los Angeles, CA 90095, USA \\ 4 Department of Basic and Translational Science, University of Pennsylvania, Philadelphia, PA 19104, USA; \\ wennan@upenn.edu (W.L.); campagno@pennmedicine.upenn.edu (K.E.C.) \\ 5 Department of Pharmacology and Chemical Biology, University of Pittsburgh, Pittsburgh, PA 15261, USA \\ 6 Department of Ophthalmology, University of Pennsylvania, Philadelphia, PA 19104, USA; \\ jamills44@gmail.com \\ 7 Kirby Center for Molecular Ophthalmology and Center for Advanced Retinal and Ocular \\ Therapeutics (CAROT), University of Pennsylvania, Philadelphia, PA 19104, USA \\ 8 Department of Medicine and Institute for Regenerative Medicine, University of Pennsylvania, \\ Philadelphia, PA 19104, USA; wenliyan@pennmedicine.upenn.edu \\ 9 Department of Physiology, University of Pennsylvania, Philadelphia, PA 19104, USA \\ * Correspondence: chm@upenn.edu; Tel.: +1-215-573-2176 \\ + These authors contributed equally.
}

Received: 14 September 2020; Accepted: 17 November 2020; Published: 24 November 2020 updates

\begin{abstract}
Cytokine release from non-inflammatory cells is a key step in innate immunity, and agonists triggering cytokine release are central in coordinating responses. P2X7 receptor (P2X7R) stimulation by extracellular ATP is best known to active the NLRP3 inflammasome and release IL-1 $\beta$, but stimulation also leads to release of other cytokines. As cytokine signaling by retinal pigmented epithelial (RPE) cells is implicated in retinal neurodegeneration, the role of P2X7R in release of cytokine IL-6 from RPE cells was investigated. P2X7R stimulation triggered IL-6 release from primary mouse RPE, human iPS-RPE and human ARPE-19 cells. IL-6 release was polarized, with predominant rise across apical membranes. IL-6 release was inhibited by P2X7R antagonists A438079, A839977, and AZ10606120, but not the NRTI lamivudine (3TC), P2X1R antagonist NF279, or P2Y1R antagonist MRS2179. P2X7R-mediated IL-6 release required extracellular $\mathrm{Ca}^{2+}$ and was blocked by $\mathrm{Ca}^{2+}$ chelator BAPTA. IL-6 release and $\mathrm{Ca}^{2+}$ elevation occurred rapidly, consistent with vesicular IL-6 staining in unstimulated cells. P2X7R stimulation did not trigger IL-1 $\beta$ release in these unprimed cells. P2X7R-mediated IL-6 release was enhanced in RPE cells from the ABCA4 ${ }^{-/}$mouse model of retinal degeneration. In summary, P2X7R stimulation triggers rapid $\mathrm{Ca}^{2+}$-dependent IL-6 release across the apical membrane of RPE cells.
\end{abstract}

Keywords: P2X7; retina; IL-6; IL-1ß; cytokine release; innate immunity; calcium-dependent vesicular release; inflammation 


\section{Introduction}

Release of cytokines from non-immune cells is a key step in innate immune responses, and the receptors that activate this cytokine release represent critical targets in controlling the response [1,2]. Stimulation of the P2X7 receptor for extracellular ATP is associated with the assembly of the NOD-, LRR- and pyrin domain-containing protein 3 (NLRP3) inflammasome and the resulting release of cytokines interleukin (IL)-1 $\beta$ and IL-18 [3,4]. As IL-1 $\beta$ is considered a "master cytokine", capable of increasing expression and release of other cytokines [5], stimulation of the P2X7 receptor can be important in coordinating components of the innate immune response. Whether the P2X7 receptor can also trigger cytokine upregulation and release independent of IL-1 $\beta$ is less well studied. This is relevant as the NLRP3 inflammasome requires "priming" to increase expression of key components, such as NLRP3 itself, before the activation stage can occur [6], and priming of inflammasome components may be rate-limiting in chronic age-dependent diseases [7]. The involvement of the P2X7 receptor in release of cytokines other than IL-1 $\beta$ may thus have implications for earlier stages in chronic inflammatory diseases.

Retinal pigmented epithelial (RPE) cells form the blood-retinal barrier in the outer retina and provide numerous supportive functions for the adjacent photoreceptors [8,9]. The innate immune responses of RPE cells have been implicated in both protective and detrimental roles in ocular pathologies [10]. While the release of inflammasome products IL-1 $\beta$ and IL-18 from RPE cells has been studied in several models of retinal stress [11-13], NLRP3 in human tissue was detected only in RPE cells adjacent to regions undergoing the terminal geographic atrophy phase of age-dependent macular degeneration [14]. This suggests that priming of NLRP3 and other components represented a late stage development, and that the cytokine response from unprimed cells may be of greater relevance in the early stages of disease.

IL-6 signaling is complex; although traditionally thought of as a pro-inflammatory cytokine, IL-6 can also have protective effects, depending on levels of the soluble IL-6 receptor [15]. Recently, IL-6 expression was reported to be elevated in RPE cells and stroma of patients with exudative age-related macular degeneration (AMD), and downregulation of IL-6 reduced subretinal fibrosis in mice models [16]. Recent work also implicated the P2X7 receptor in the release and upregulation of IL-6 in optic nerve head astrocytes and retinal ganglion cells [17].

The current study examines whether stimulation of the P2X7 receptor can trigger release of cytokine IL-6 from unprimed RPE cells. The findings suggest that the P2X7 receptor can trigger a rapid release of IL-6 from RPE cells that is dependent on increased intracellular $\mathrm{Ca}^{2+}$ and not reliant on IL-1 $\beta$.

\section{Materials and Methods}

\subsection{Isolation and Culture of Mouse RPE Cells}

All mice were treated in accordance with University of Pennsylvania Institutional Animal Care and Use Committee (IACUC \#804588). Mice were reared at 5-15 lux and sacrificed with a $\mathrm{CO}_{2}$ overdose. Mouse eyes were isolated and processed as described previously [18]. In brief, after enucleation, intact eyes were incubated in $2 \%$ dispase and $0.4 \mathrm{mg} / \mathrm{mL}$ collagenase IV for $45 \mathrm{~min}$. Eyes were then incubated for 20 min in growth medium containing Dulbecco's Modified Eagle Medium (DMEM) and Ham's F12 medium with $3 \mathrm{mM}$ L-Glutamine, $100 \mu \mathrm{g} / \mathrm{mL}$ streptomycin, and $2.5 \mathrm{mg} / \mathrm{mL}$ Fungizone and/or $50 \mu \mathrm{g} / \mathrm{mL}$ gentamicin and 10\% fetal bovine serum (FBS, all Thermo Fisher, Inc., Waltham, MA, USA). Globes were separated at the ora serata, the retina removed and sheets of RPE cells were dissected away from the choroid with fine forceps. These RPE sheets were collected in growth media and triturated to form single cell suspensions. Mouse RPE cells were seeded onto surfaces coated with $0.05 \%$ poly-L-lysine and $10 \mu \mathrm{g} / \mathrm{mL}$ laminin. ABCA4 ${ }^{-/-}$mice were a kind gift from Dr. Gabriel Travis of the Jules Stein Eye Institute, UCLA. All materials were purchased from Sigma Chemical Corp (St. Louis, MO, USA) unless otherwise indicated. 


\subsection{Human Induced Pluripotent Stem (iPS) Cell Culture and Differentiation into Induced RPE Cells}

Undifferentiated iPS cells (Control 1 (CHOPWT10). Control 2 (PENN123i-SV20)), and Control 3 (PENN067i-312-1) were derived and characterized as previously published $[19,20]$. The University of Pennsylvania human subjects research Institutional Review Board (IRB \#814132) approved the collection of samples and all subjects gave written informed consent. Induced pluripotent stem cells were maintained in pluripotent stem cell (PSC) medium (DMEM/F12 (50:50), 1× Glutamax, $1 \times$ penicillin/streptomycin, $15 \%$ knockout serum replacement, $1 \mathrm{x}$ non-essential amino acids, $0.1 \mathrm{mM}$ $\beta$-mercaptoethanol, and $10 \mathrm{ng} / \mathrm{mL}$ of basic fibroblast growth factor on $0.1 \%$ gelatin coated dishes (all Thermo Fisher, Inc.). Following the protocol Duong et al. [21], feeder-free differentiation conditions, small molecules, and growth factors were used to induce the generation of RPE cells. At day 35 of differentiation, cells were harvested using accutase and passaged twice in $1 \%$ growth factor reduced Matrigel coated dishes in X-Vivo 10 media plus $2 \mu \mathrm{M}$ of thiazovivin for one day, followed by X-Vivo 10 media alone. Cells were also grown on 12-well Transwell inserts with $0.4 \mu \mathrm{m}$ pore size (Corning Inc, Corning, NY, USA). An EVOM2 system (World Precision Instruments, Sarasota, FL, USA) with a STX2 probe was used to measure total transepithelial electrical resistance (TEER) once a week. All TEER values were normalized to the area of the membrane $\left(1.44 \mathrm{~cm}^{2}\right)$ and corrected for the resistance without cells.

\subsection{ARPE-19 Cells}

ARPE-19 cells (ATCC, Manassas, VA, USA) were grown to confluence in $25 \mathrm{~cm}^{2}$ primary culture flasks in a 1:1 mixture of DMEM/F12 with $3 \mathrm{mM}$ L-Glutamine, $100 \mu \mathrm{g} / \mathrm{mL}$ streptomycin, $100 \mathrm{U} / \mathrm{mL}$ penicillin, and 10\% FBS (all Thermo Fisher, Inc.) as described [22]. The concentration of FBS was reduced to $1 \%$ upon confluence to encourage differentiation. Cells were grown on standard tissue culture plates or Transwell inserts using the methods described above.

\subsection{Cytokine Measurement}

After washing, cells were incubated with P2X7 receptor agonist 2'(3')-O-(4-Benzoylbenzoyl) adenosine- $5^{\prime}$-triphosphate (BzATP) and supernatant was collected at the indicated times. IL-6 levels were determined using the QuantiGlo IL-6 Immunoassay or Quantikine enzyme-linked immunosorbent assay (ELISA) kits (both R\&D Systems, Minneapolis, MN, USA) with signal detected using a luminometer (Thermo Fisher, Inc.) or SpectraMax Absorbance reader (Molecular Devices, San Jose, CA, USA), respectively. Parallel approaches were used to detect IL-1 $\beta$ levels using the QuantiGlo Human IL-1B/IL-1F2 Immunoassay (R\&D Systems). $\mathrm{Mg}^{2+}$-free isotonic solution [(in mM) $105 \mathrm{NaCl}$, $5 \mathrm{KCl}, 6 \mathrm{HEPES}$ acid, $4 \mathrm{Na}$ HEPES, $5 \mathrm{NaHCO}_{3}, 60$ mannitol, 5 glucose, and $1.3 \mathrm{CaCl}_{2}$ ] was used in some experiments as $\mathrm{Mg}^{2+}$ is reported to block the P2X7 receptor [23]. The absolute levels of IL-6 varied across experiments, perhaps due to small differences in extracellular volume or the freshness of the IL-6 solution used for standard curves.

\subsection{P2X7, P2X1 and P2Y1 Antagonists}

Cells were washed with $\mathrm{Mg}^{2+}$-free isotonic solution then preincubated with antagonists for $15 \mathrm{~min}$ at $37^{\circ} \mathrm{C}$. Solution was replaced with one containing isotonic control solution or BzATP \pm antagonist. Cells were incubated for $30 \mathrm{~min}$ at $37^{\circ} \mathrm{C}$, after which supernatant was collected. IL-6 levels were determined with using a Quantikine ELISA kit as described above. Antagonists used were P2X7 antagonists A438079, AZ10606120, A839977, P2X1 antagonist NF 279, P2Y1 antagonist MRS2176, and lamivudine (3TC). All antagonists were purchased from Tocris/Biochine Corp. (Minneapolis, MN, USA) except for lamivudine (Toronto Research Chemicals, Toronto, ON, Canada). 


\subsection{Calcium Measurements}

Intracellular $\mathrm{Ca}^{2+}$ was measured based on methods previously described in detail [24]. In brief, ARPE-19 cells were grown and loaded with $5 \mu \mathrm{M} \mathrm{Ca}^{2+}$ indicator dye Fura-2 AM and $2 \%$ pluronic F127 (Thermo Fisher, Inc.). Coverslips were mounted in a perfusion chamber and cells visualized using a $\times 40$ objective on a Nikon Diaphot microscope (Nikon USA, Melville, NY, USA). The fura- 2 dye in cells was alternatively excited at 340 and $380 \mathrm{~nm}$, and the fluorescence emitted $>520 \mathrm{~nm}$ was imaged with a charge-coupled device camera and analyzed (all Photon Technologies International, Lawrenceville, NJ, USA). Calibration was performed using ionomycin in the presence of high $\mathrm{Ca}^{2+}$ and $\mathrm{Ca}^{2+}$ free solutions at $\mathrm{pH}$ 8.0.

\subsection{Immunocytochemistry}

ARPE-19 cells were fixed with $4 \%$ paraformaldehyde in $100 \mathrm{mM}$ phosphate buffered saline (PBS) for $15 \mathrm{~min}$. After washing, cells were permeabilized and autofluorescence quenched in PBS containing $20 \mathrm{mM}$ glycine, $75 \mathrm{mM}$ ammonium chloride and $0.1 \%$ Triton X-100 for $8 \mathrm{~min}$, followed by a $2 \mathrm{~min}$ incubation with this solution plus $0.5 \%$ sodium dodecyl sulfate. Cells were blocked in $0.25 \%$ fish skin gelatin, $0.025 \%$ saponin and $10 \%$ donkey serum in PBS for $1 \mathrm{~h}$ at $25^{\circ} \mathrm{C}$, followed by $5 \mathrm{~min}$ in high salt PBS. Cells were incubated overnight in a rabbit primary polyclonal antibody against IL-6 (Abcam, Cambridge, MA, USA; \#ab6672, 1:500 in blocking solution) at $4{ }^{\circ} \mathrm{C}$. After washing, cells were incubated for $1 \mathrm{~h}$ donkey anti-rabbit Alexa 488 (Abcam, 1:1000, in blocking solution) and F-actin counterstain (Alexa-594 phalloidin, 1:1000, Thermo Fisher Inc.) at $25^{\circ} \mathrm{C}$. Nuclei were counterstained with 4',6-diamidino-2-phenylindole (DAPI; 1:10,000, $1 \mathrm{~min}$ ). Antibody-antigen binding was fixed for $15 \mathrm{~min}$ in 4\% paraformaldehyde. Staining was visualized using a Nikon Eclipse E600 epifluorescence microscope, and separate channels combined using Adobe Photoshop (San Jose, CA, USA) according to accepted protocols.

\subsection{Data Analysis}

All data are expressed as mean \pm standard error of the mean. Significance was defined as $p<0.05$ and was determined using a student's t-test or one-way Analysis of Variance (ANOVA) with the F value (degrees of freedom for numerator/denominator), followed by appropriate Post-hoc test. Data were analyzed using SigmaStat software (Systat Software, Inc., San Jose, CA, USA) or GraphPad Prism version 8.0.0 for Windows (GraphPad Software, San Diego, CA, USA, www.graphpad.com).

\section{Results}

\subsection{IL-6 Release Triggered by P2X7 Receptor Activation in Mouse, iPS-RPE and ARPE-19 Cells}

Initial experiments asked whether stimulation of the P2X7 receptor with agonist BzATP triggered release of cytokine IL-6 from primary cultures of mouse RPE cells. Mouse RPE cells were grown until confluent (Figure 1A). Exposure of cells to $50 \mu \mathrm{M}$ BzATP for $1 \mathrm{~h}$ increased the concentration of IL-6 in the bath over three-fold, from $31 \mathrm{pg} / \mathrm{mL}$ in control to $99 \mathrm{pg} / \mathrm{mL}$ in cells exposed to BzATP (Figure 1B). While these absolute levels are low, the minimum volume of solution needed to keep the cells moist had a height of $\sim 3 \mathrm{~mm}$, while the extracellular distance in vivo is submicron [25], suggesting cytokine concentration could be several orders of magnitude higher in vivo. BzATP also triggered a release of IL-6 from RPE cells derived from human iPS cells. Cells were grown for at least 2 weeks and had a cobblestone appearance (Figure 1C). BzATP exposure increased levels of IL-6 outside of iPS-RPE cells three-fold, from $66 \mathrm{pg} / \mathrm{mL}$ in control media to $201 \mathrm{pg} / \mathrm{mL}$ with BzATP exposure (Figure 1D).

Additional experiments were performed on the cultured human ARPE-19 cell line; cells were grown for 14 days with the last 10 days in $1 \%$ FBS to encourage a more mature phenotype [26] (Figure 1E). IL-6 levels were $28 \mathrm{pg} / \mathrm{mL}$ two h after addition of control medium, but rose to $106 \mathrm{pg} / \mathrm{mL}$ when BzATP $(500 \mu \mathrm{M})$ was added to the medium (Figure 1F). The similarity in the responses from 
mouse RPE cells, iPS-RPE cells and ARPE-19 cells strongly suggests that release of IL-6 from RPE cells is a common response to stimulation of the $\mathrm{P} 2 \mathrm{X} 7$ receptor.

A

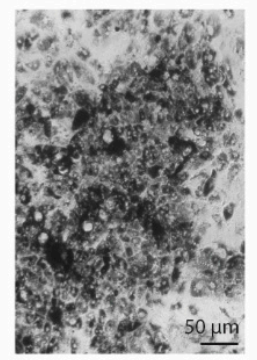

B

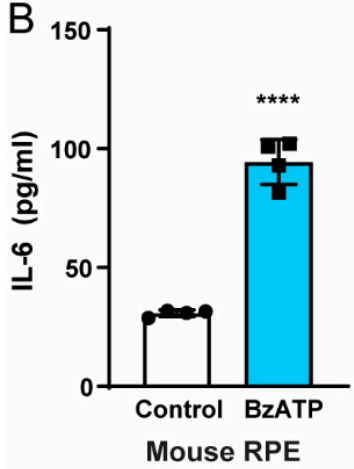

C
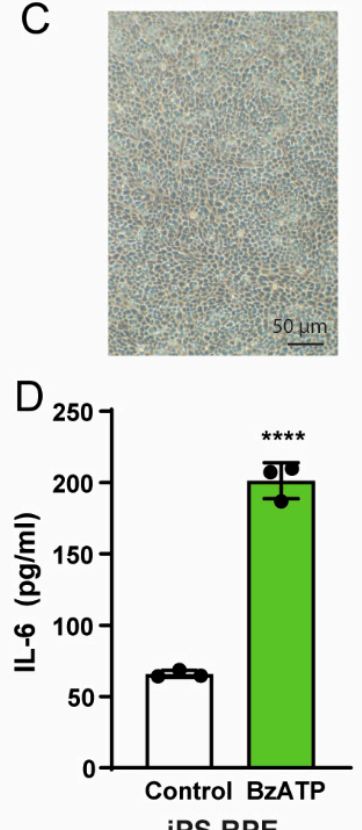

$\mathrm{E}$

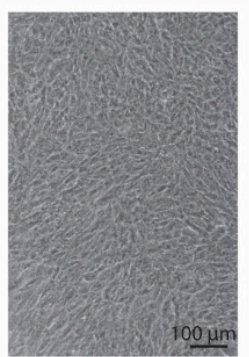

F

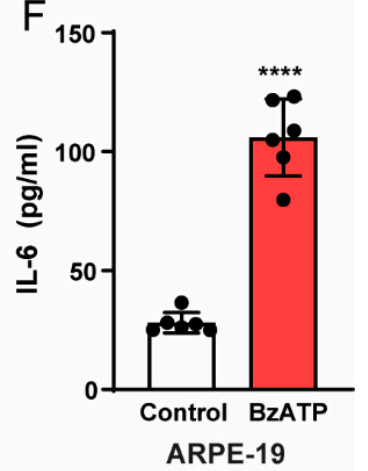

Figure 1. BzATP triggers IL-6 release from mouse, iPS-derived RPE cells and ARPE-19 cells. (A) Representative image of cultured mouse RPE cells, 11 days after plating. (B) Levels of IL-6 in the bath from primary cultures of mouse RPE cells increases when exposed to $50 \mu \mathrm{M}$ BzATP for $1 \mathrm{~h}$ $(* * * * p<0.001, n=4)$. (C) Image of iPS-derived RPE cells 8 days after plating. (D) iPS-RPE released IL-6 in response to BzATP $\left(500 \mu \mathrm{M}, 2 \mathrm{~h} ;{ }^{* * * *} p<0.001, n=3\right)$. (E) ARPE-19 cells 10 days after plating.

(F) ARPE-19 cells released IL-6 in response to BzATP $(500 \mu \mathrm{M}, 2 \mathrm{~h}$; $* * * *<0.001, n=6)$.

\subsection{Polarity of P2X7 Receptor Stimulation and IL-6 Release}

RPE cells form part of the blood retinal barrier, with their apical membrane facing the outer segments of retinal photoreceptors and their basolateral membrane adjacent to the choroidal blood supply [27]. While previous immunohistochemical staining of mouse retina suggested the P2X7 receptor was present on both apical and basolateral membranes [28], the polarity of IL-6 release to stimulation from either side was examined to focus on functional polarity. iPS-RPE cells were grown on permeable cell culture inserts for several months; the transepithelial electrical resistance (TEER) rose to $290 \Omega \cdot \mathrm{cm}^{2}$ after 8 weeks (Figure 2A), consistent with the establishment of tight junctions and polarity [29]. Baseline levels of IL-6 in control solutions were low in chambers facing both apical and basolateralmembranes, although levels were $>5$-fold higher in samples taken from the apical chamber as compared to the basal chamber (Figure 2B). Addition of BzATP to the apical chamber increased levels of IL-6 in both chambers, but concentrations in the apical chamber were $>5$-fold greater than the basal chamber.

Polarity experiments were repeated in ARPE-19 cells grown on permeable cell culture inserts. TEER rose to $59 \Omega \cdot \mathrm{cm}^{2}$ after 8 weeks and remained stable at this level (Figure $2 \mathrm{C}$ ), consistent with levels previously reported [29], and significantly lower than TEER in iPS-RPE cells $(p<0.0001)$. In spite of the reduced TEER levels, however, the pattern of polarized IL-6 release from ARPE-19 cells was similar to that from iPS-RPE cells (Figure 2D). Addition of BzATP to the apical chamber led to a large IL-6 release, with levels in the apical chamber four-fold greater than the basal chamber. The main difference between the responses in the iPS-RPE and ARPE-19 cells was a general reduction in IL-6 concentration, and a greater response to basal application of BzATP; whether this reflects P2X7 receptors on the basolateral membrane of ARPE-19 cells or seepage of BzATP due to the lower TEER is unknown. 
Regardless, results from both iPS-RPE and ARPE-19 cells indicate that the primary release of IL-6 occurred across the apical membrane, with the greatest response found when BzATP was applied to the apical membrane.

A.

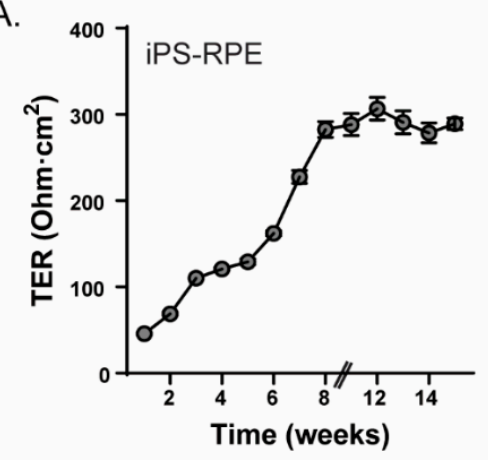

C.

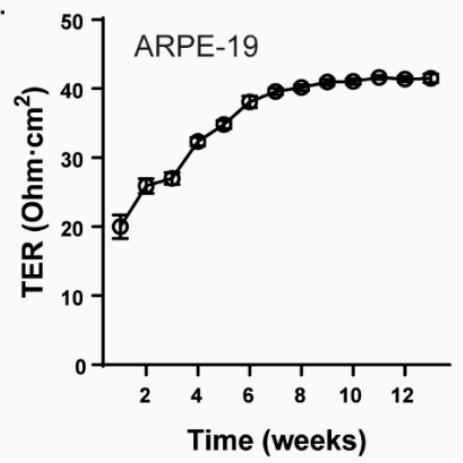

B.

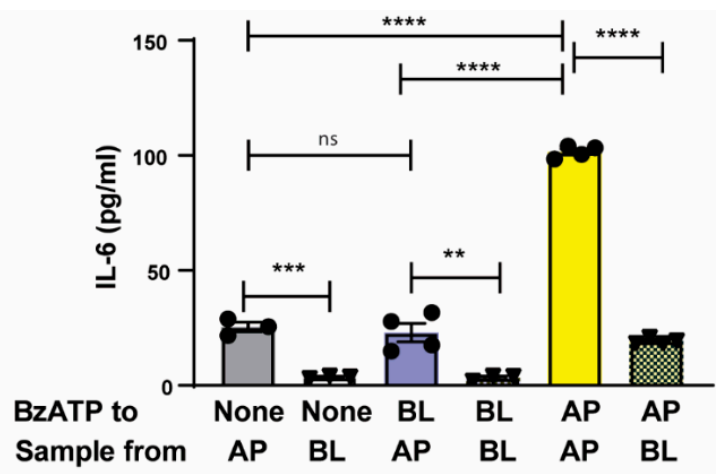

D.

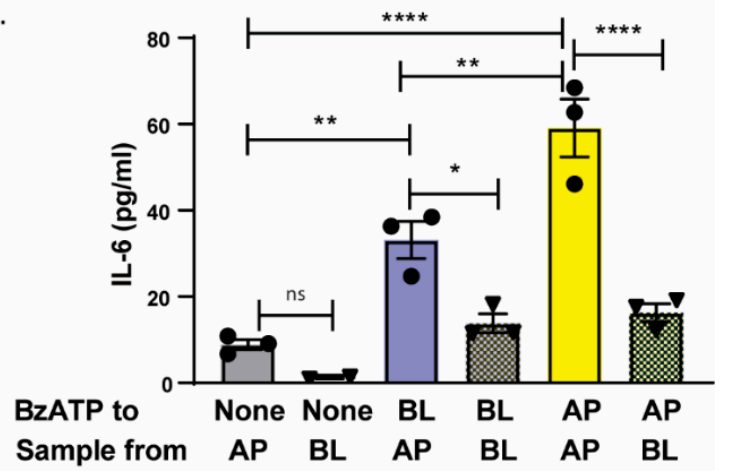

Figure 2. Polarity of IL-6 release. (A) Time-dependent changes in TEER of iPS-RPE cells grown on Transwell chambers. Symbols represent the mean \pm SEM $(n=11)$. (B) Polarized release of IL-6 from iPS-RPE cells sampled from the apical (AP) or basolateral (BL) sides of the Transwell insert $2 \mathrm{~h}$ after $500 \mu \mathrm{M}$ BzATP was added to the apical (AP), basolateral (BL) or neither (None) compartment. One way ANOVA $\mathrm{F}(5,15)=308.0, p<0.0001$ with Tukey post hoc test ${ }^{* * *} p<0.01{ }^{* * *} p<0.001{ }^{* * * * *} p<0.0001$, ns $=$ not significant; $n=3-4$ ). (C) Time-dependent increases in TEER of ARPE-19 cells grown in Transwell inserts. Symbols represent the mean \pm SEM $(n=20-30)$. (D) Polarized release of IL-6 from ARPE-19 cells sampled from the apical (AP) or basolateral (BL) sides of the Transwell chamber $2 \mathrm{~h}$ after $500 \mu \mathrm{M}$ BzATP was added to the apical (AP), basolateral (BL) or neither (None) compartment. One way ANOVA F $(5,11)=30.56, p<0.0001$ with Tukey's post-hoc test, ${ }^{*} p<0.05,{ }^{* *} p<0.01,{ }^{* * * *} p<0.0001$, ns $=$ not significant.

\subsection{Pharmacological Validation of the P2X7 Receptor}

The P2X7 receptor has been previously identified in RPE cells by multiple groups using immunohistochemistry, PCR, and functional analysis [28,30-32]. Although BzATP is widely used as an agonist for the P2X7 receptor, it can also interact with P2X1 and P2Y1 receptors [33-36]. To confirm that the actions of BzATP were mediated by the P2X7 receptor, multiple antagonists were tested for their ability to block the release of IL-6 from RPE cells in the presence of BzATP (Figure 3). Competitive P2X7 antagonist A438079 significantly blocked the release of IL-6 triggered by BzATP; A438079 had little or no activity at other P2X receptors [35]. The actions of BzATP were also blocked by AZ10606120, a negative allosteric modulator of the human P2X7 receptor [37], and by antagonist A839977 [38]; all three antagonists produced a near complete block of IL-6 release. Lamivudine (3TC) is used clinically as a nucleoside reverse transcriptase inhibitor but has also been shown to inhibit the actions of the P2X7 receptor in mice [39]. However, the reduction in BzATP-mediated IL-6 release by 3TC was not significant. Likewise, neither P2Y1 antagonist MRS2176 nor P2X1 antagonist NF 279 produced a 
significant reduction in IL-6 levels in the presence of BzATP. Taken together, these results suggest that the P2X7 receptor is primarily responsible for the BzATP-mediated release of IL-6 from RPE cells.

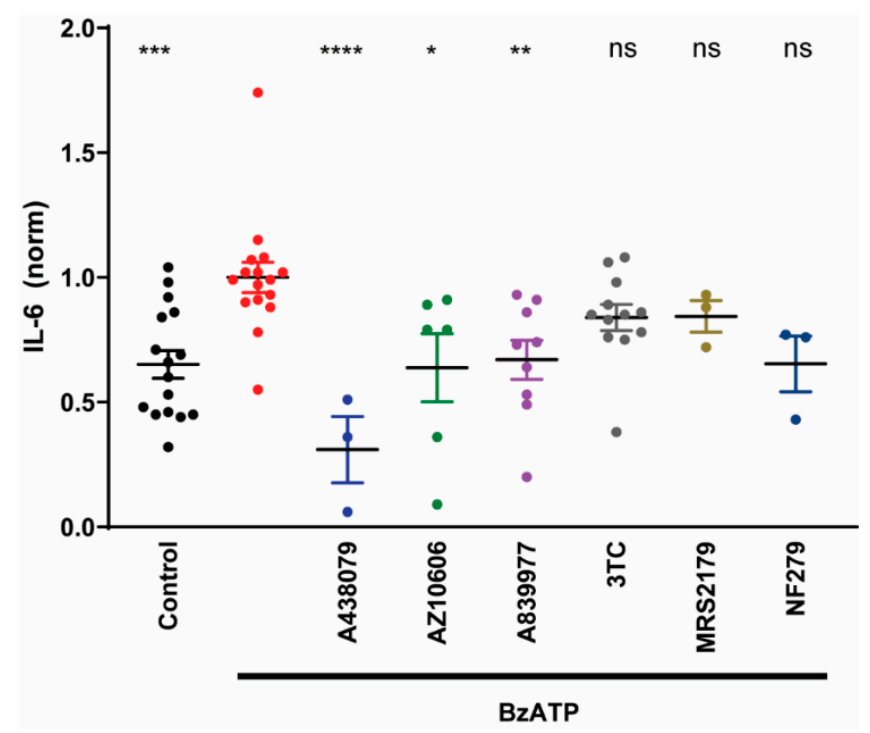

Figure 3. Pharmaceutical validation of P2X7 receptor. Exposure of ARPE-19 cells to $100 \mu \mathrm{M} \mathrm{BzATP}$ in isotonic solution for 30 min triggered a release of IL-6 ( ${ }^{* *}$ vs. Control, $\left.p=0.0005, n=13\right)$. In the presence of BzATP, IL-6 release was reduced by P2X7 antagonists A438079 (50 $\mu \mathrm{M},{ }^{* * * *} p<0.0001$, $\left.n=3), \operatorname{AZ10606120~(50\mu M~AZ10606,~}{ }^{*} p=0.0113, n=6\right)$ and A839977 (50 $\left.\mu \mathrm{M},{ }^{* *} p=0.0071, n=9\right)$. No significant reduction (ns) in IL-6 levels was found when lamivudine (3TC, $100 \mu \mathrm{M}, n=12$ ), MRS2176 (300 nM, $n=3$ ) or NF 279 (50 nM, $n=3$ ) were added in the presence of BzATP. One way ANOVA $(\mathrm{F} 97,60)=5.42, p<0.0001$; Dunnett's multiple comparisons test vs. BzATP alone.

\subsection{IL-6 Release through Rapid Rise in $\mathrm{Ca}^{2+}$}

The P2X7 receptor is an ionotropic channel permeable to cations including $\mathrm{Ca}^{2+}[40]$, and the electrochemical gradients imply a substantial entry of $\mathrm{Ca}^{2+}$ into the RPE cells after receptor stimulation under physiological conditions. $\mathrm{As} \mathrm{Ca}^{2+}$ is implicated in the release of numerous cytokines, the requirement for extracellular $\mathrm{Ca}^{2+}$ in the BzATP-mediated release of IL- 6 was examined. While application of BzATP released IL-6 in the presence of control solution containing a physiologically relevant $1.3 \mathrm{mM}$ extracellular $\mathrm{Ca}^{2+}$, the response was abolished when extracellular $\mathrm{Ca}^{2+}$ was removed (Figure 4A). To confirm a role for intracellular $\mathrm{Ca}^{2+}$ in the release of IL-6, cells were exposed to $20 \mu \mathrm{M}$ cell permeable calcium chelator bis(2-aminophenoxy)ethane tetraacetic acid acetoxymethyl (BAPTA-AM); cells were preincubated for $1 \mathrm{~h}$ in BAPTA-AM, then exposed to BzATP in the presence of BAPTA-AM. BAPTA-AM prevented the rise of IL-6 in cells exposed to BzATP (Figure 4B).

The magnitude and time course of changes to cytoplasmic $\mathrm{Ca}^{2+}$ in response to BzATP application were determined. Cytoplasmic $\mathrm{Ca}^{2+}$ rose rapidly after application of BzATP, with robust, reversible, and repeatable spikes of $\mathrm{Ca}^{2+}$ found after application of BzATP for only $15 \mathrm{~s}$ (Figure 4C). To determine whether IL-6 release also showed a rapid response, cells were exposed to BzATP for only 1 min; this brief exposure led to a significant, albeit small, release of IL-6 (Figure 4D). Together, these rapid rises in cytoplasmic $\mathrm{Ca}^{2+}$ and extracellular IL-6 release suggested the influx of $\mathrm{Ca}^{2+}$ acted upon pre-formed stores of IL-6. Immunocytochemistry of baseline, unstimulated cells detected IL-6 in round clusters, consistent with vesicular staining of IL-6 (Figure 4E). Together, these observations are consistent with a mechanism in which the rapid elevation of cytoplasmic $\mathrm{Ca}^{2+}$ following stimulation of the P2X7 receptor leads to fusion of pre-formed vesicles containing IL-6 with the plasma membrane and release of IL-6 across this membrane. 

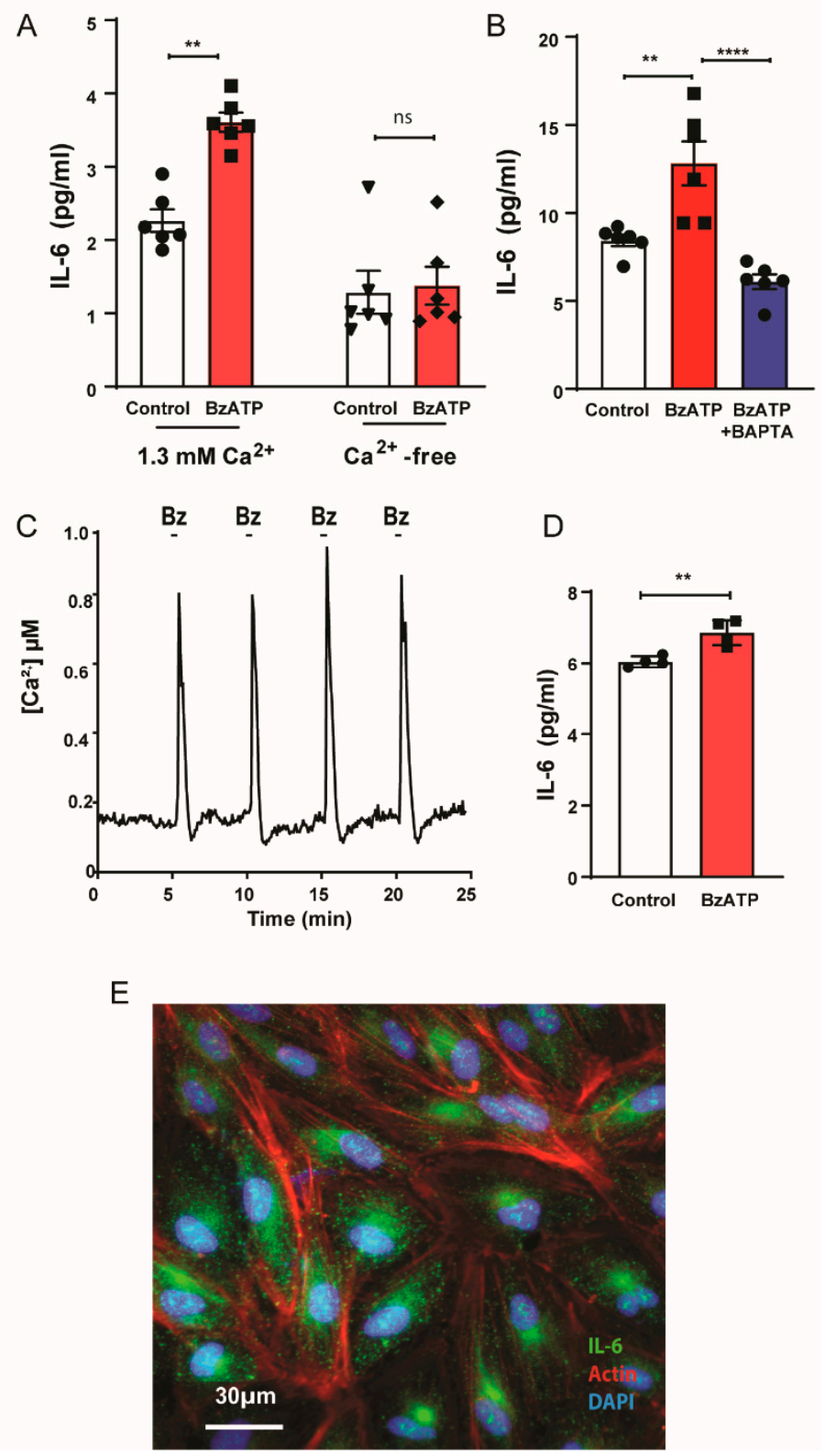

Figure 4. Calcium and IL-6 release from ARPE-19 cells. (A) The release of IL-6 triggered by BzATP $(50 \mu \mathrm{M})$ was dependent upon extracellular $\mathrm{Ca}^{2+}$. (One-way ANOVA $\mathrm{F}(3,20)=23.89 p<0.0001$; Tukey's post hoc test; ${ }^{* *} p=0.0018, \mathrm{~ns}=$ not significant, $n=6$ ). IL-6 levels were significantly increased after 15 min in $\mathrm{Ca}^{2+}$ containing isotonic solution with $1.3 \mathrm{mM} \mathrm{Ca}^{2+}$, but the rise in $\mathrm{Ca}^{2+}$ associated by BzATP was abolished in $\mathrm{Ca}^{2+}$-free solution. (B) Chelation of $\mathrm{Ca}^{2+}$ with $20 \mu \mathrm{M}$ BAPTA-AM prevented the release of IL-6 after 30 min with BzATP $(200 \mu \mathrm{M})$ One-way ANOVA F $(2,15)=19.17 p<0.0001$; Dunnet's post hoc test $\left.{ }^{* * * *} p<0.0001 ;{ }^{* *} p=0.0018, n=6\right)$. (C) BzATP $(50 \mu \mathrm{M})$ led to a rapid rise in intracellular calcium when applied for $15 \mathrm{~s}$ that was reversible and repeatable. (D) Exposure to $50 \mu \mathrm{M}$ BzATP for $1 \mathrm{~min}$ led to a small but significant IL-6 release (unpaired $t$-test ${ }^{* *} p=0.005, n=4$ ). Experiments in (A-D) were performed in the absence of $\mathrm{Mg}^{2+}$ to prevent its block of the P2X7 receptor. (E) Particulate staining for IL-6 in unstimulated cells; Actin (phaloidin red), DAPI (blue).

\subsection{P2X7 Receptor and IL-1 $\beta$ Release}

The master cytokine IL-1 $\beta$ has been reported to lead to a secondary upregulation and release of IL-6 [41]. In RPE cells, release of IL-6 was previously shown to be stimulated by exposure to IL-1 $\beta$ for $4 \mathrm{~h}$ [42]. Given that the P2X7 receptor is associated with assembly and activation of the NLRP3 inflammasome, which in turn leads to the maturation and release of IL-1 $\beta$ [6], we asked whether the 
release of IL- 6 evoked by P2X7 receptor stimulation was due to IL-1 $\beta$ release. BzATP did not lead to the release of IL- $1 \beta$ under the unprimed conditions associated with IL- 6 release. There was no difference in the levels of IL-1 $\beta$ in the bath 15 and 30 min after addition of BzATP when compared to levels in control isotonic solution (Figure 5A,B). To ensure the lack of response did not reflect the absence of a key substance in the environment, experiments were repeated in cell media. Cells were incubated in BzATP for $15 \mathrm{~min}$, and $30 \mathrm{~min}$ in growth media, and to examine the effect of prolonged stimulation, cells were exposed to BzATP for $24 \mathrm{~h}$, but again, BzATP had no effect on levels of IL-1 $\beta$ (Figure 5C). Of note, neither these cells, nor the ones showing IL-6 release in Figures 1-4, were primed with lipopolysaccharide to prime the NLRP3 inflammasome. Together, these findings imply that the release of IL- 6 triggered by P2X7 activation did not require IL-1 $\beta$.
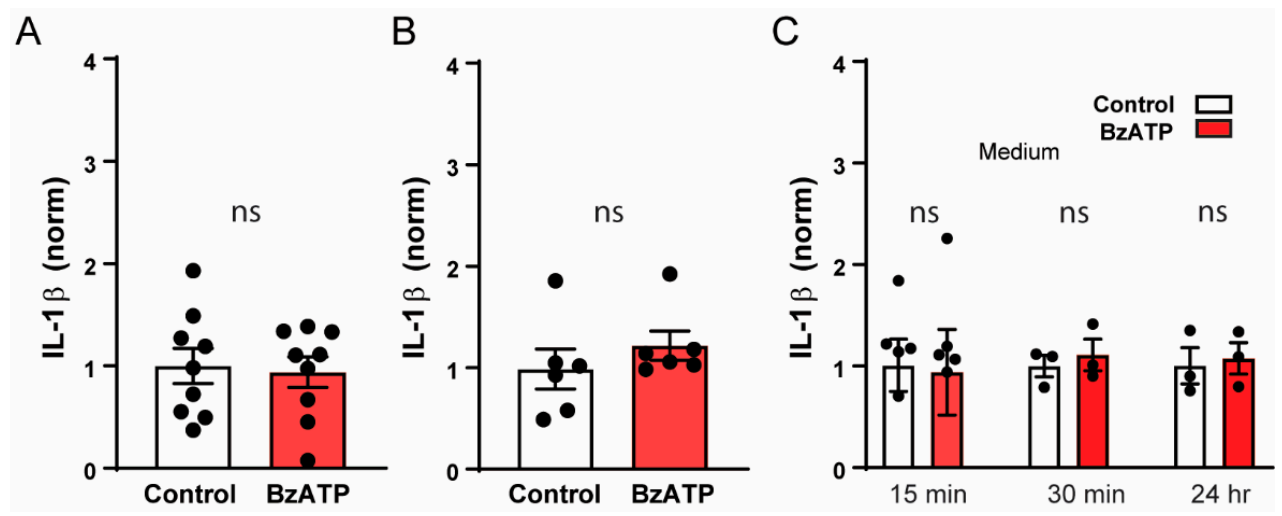

Figure 5. Stimulation of P2X7 receptor did not trigger release of IL-1 $\beta$ from unprimed ARPE-19 cells. The levels of IL-1 $\beta$ in the bath surrounding cells in control isotonic (white) and $50 \mu \mathrm{M}$ BzATP (red) solutions after $15 \min (\mathbf{A} ; n=9, p=0.79)$ or $30 \mathrm{~min}(\mathbf{B} ; n=6, p=0.37)$. (C) Cells in growth media were incubated in BzATP for $15 \mathrm{~min}(n=6), 30 \mathrm{~min}(n=3)$ and $24 \mathrm{~h}(n=3)$, but there was no rise in bath levels of IL-1 $\beta$. One -way ANOVA F $(5,18)=0.033, p=0.9993$.

\subsection{Enhanced IL-6 Release from ABCA4 ${ }^{-/}$RPE Cells}

The $\mathrm{ABCA} 4^{-/-}$mouse is a model of recessive Stargardt's retinopathy with known defects in both RPE and photoreceptor cells [43]. We have previously shown that expression of the P2X7 receptor is elevated in RPE cells from the ABCA4 $4^{-/}$mouse [28]. As sampling in the subretinal space is difficult, we cultured RPE cells from ABCA4 ${ }^{-/-}$mice and control C57Bl6 mice to determine if IL-6 levels were indeed higher after stimulation of the P2X7 receptor. Exposure to BzATP was associated with increased levels of IL-6 bathing RPE cells from ABCA4 ${ }^{-/-}$mice as compared to wildtype controls (Figure 6).

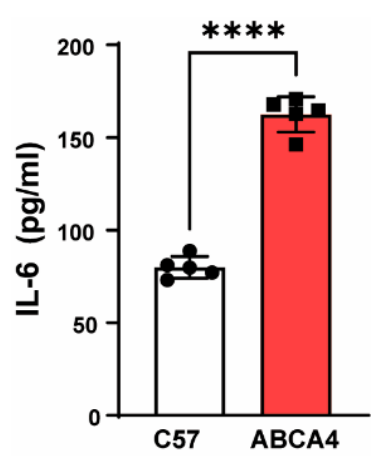

Figure 6. P2X7 preceptor-mediated IL-6 release increased in ABCA4 ${ }^{-/-}$RPE cells. Primary cultures of RPE cells from C57Bl6 and ABCA4 ${ }^{-/-}$mice were exposed to IL-6 for $1 \mathrm{~h}$, after which the supernatant was collected and IL-6 levels determined. ${ }^{* * *} p<0.0001, n=5$. 


\section{Discussion}

The primary conclusions from this study are that stimulation of the P2X7 receptor leads to the release of cytokine IL- 6 from RPE cells. The release can be rapid, requires influx of $\mathrm{Ca}^{2+}$ from outside, and is independent of IL- $1 \beta$. The detection of the IL- 6 release in response to BzATP from primary cultures of mouse RPE cells, RPE cells derived from human iPS cells, and from the ARPE-19 cell line demonstrates the wide-spread nature of the response.

It is difficult to accurately sample IL-6 levels in vivo, given that the sub-retinal space separating RPE cells and photoreceptors is only 10-20 nm across [44], and the complex extracellular layers of Bruch's membrane on the basolateral membrane preclude non-invasive sampling [45]. This difficulty is compounded by the nature of extracellular ATP signaling; intracellular levels of ATP are several orders of magnitude greater that extracellular concentrations, and ATP is widely released in response to mechanical stimulation. Probes that push against and rupture cells can themselves lead to release of ATP during attempts to obtain samples of extracellular ATP $[46,47]$. While measurements from cultured cells cannot completely recapitulate the in vivo situation, the identification of the P2X7 receptor on RPE cells in vivo using molecular, protein, and functional assays [28,32,48], combined with the use of three different cell models in the current study in Figure 1 helps overcome these limitations and supports the response across species and cell types. The detection of polarized IL-6 release in response to BzATP from iPS-RPE and ARPE-19 cells grown on permeable supports shown in Figure 2 adds to the relevance of this release.

\subsection{Identification of $P 2 X 7$ Receptors}

ATP is the endogenous agonist for the P2X7 receptor [49], but its low sensitivity (pEC 50 of 2.6 in mouse and 4.1 in human P2X7 receptors), combined with its ability to stimulate other P2X and P2Y receptors at lower concentrations, makes BzATP preferable as an experimental agonist $[35,50]$. BzATP activates the P2X7 receptor at lower concentrations than ATP ( $\mathrm{pEC}_{50}$ of 4 and 5.3 at mouse and human P2X7 receptors, respectively). The demonstration that three different antagonists inhibit the ability of BzATP to trigger IL-6 release increased confidence for involvement of the P2X7 receptor in the current study. The specificity of antagonist A438079 for the P2X7 receptor makes involvement of other receptors unlikely [35]. A839977 is a tetrazole derivative with a high degree of specificity and selectivity for the P2X7 receptor [38,51]. The reduction of IL-6 release in the presence of negative allosteric modulator AZ10606120 further supports receptor identity [37]. Although BzATP can also act at P2X1 and P2Y1 receptors [33,34,36], neither P2X1 antagonist NF 279 nor P2Y1 antagonist MRS2176 significantly reduced the BzATP-mediated release of IL-6. Together, the data in Figure 3 strongly implicate the P2X7 receptor in the release of IL- 6 triggered by BzATP.

\subsection{Mechanism of Release P2X7 Receptor-Mediated IL-6 Release}

The results presented in Figure 4 are consistent with IL-6 release following the influx of $\mathrm{Ca}^{2+}$ after stimulation of the P2X7 receptor. The P2X7 receptor is an ionotropic cation channel with substantial permeability to $\mathrm{Ca}^{2+}$; careful calculation of the relative permeability of the channel from the fractional contribution of $\mathrm{Ca}^{2+}$ to the total ATP-gated membrane current suggest the channel has $P_{\mathrm{Ca}} / P_{\mathrm{Na}} \leq 1$ [52]. The absence of IL- 6 release in $\mathrm{Ca}^{2+}$-free solutions, combined with the lack of release in the presence of $\mathrm{Ca}^{2+}$ chelator BAPTA, the detection of IL-6 release within minutes, the rapid elevation of intracellular $\mathrm{Ca}^{2+}$ following application of BzATP, and the presence of IL-6 staining with vesicular patterning in unstimulated cells all support the hypothesis that $\mathrm{Ca}^{2+}$ entry rapidly triggers IL-6 release from preformed vesicles. The detailed mechanisms underlying the release of IL-6 triggered by the P2X7 receptor from RPE cells are unknown, however. $\mathrm{Ca}^{2+}$-dependent vesicular release is usually due to binding of $\mathrm{Ca}^{2+}$ to synaptotagmins and activation of SNARE machinery [53,54], and synaptotagmin 1 is constitutively expressed in RPE cells [55]. It was recently reported that, in astrocytes, stimulation of the P2X7 receptor led to IL-6 release after 5-6 h through involvement 
of NADPH oxidase and ROS production downstream of $\mathrm{Ca}^{2+}$ entry [56]. In microglial cells, $24 \mathrm{~h}$ exposure to BzATP increased expression of IL-6 mRNA and release of IL-6, while $4 \mathrm{~h}$ exposure to BzATP increased immunocytochemical staining for IL-6 [57]. The rapid release of preformed cytokines is usually associated with classic innate immune cells types such as eosinophils, mast cells, and neutrophils [53], so the presence of rapid $\mathrm{Ca}^{2+}$-dependent IL-6 release in RPE cells may be of interest.

While evidence for a rapid $\mathrm{Ca}^{2+}$-dependent release of IL-6 after P2X7 receptor stimulation is strong, elevation of IL-6 expression cannot be ruled out on a longer time scale. In isolated optic nerve head astrocytes, IL-6 expression was increased $4 \mathrm{~h}$ after exposure to BzATP, while intravitreal injection of BzATP increased retinal IL-6 expression after 24 h [17]. Expression of IL-6 can also be increased by IL-1 $\beta$, with increased release detected after $4 \mathrm{~h}$ [42]. However, the rapid time course of IL- 6 release in RPE cells, combined with data in Figure 5 showing the inability of BzATP to trigger IL-1 $\beta$ release under the same conditions capable of causing IL-6 release, imply that the IL- 6 response is independent of IL-1 $\beta$. This study does not negate the possibility that, under conditions where the NLRP3 inflammasome is "primed", P2X7 receptor stimulation could release IL-1 $\beta$ and lead to a secondary upregulation and/or release of IL-6. Of relevance here is the recent report that P2X7 receptors can increase the priming of inflammasome genes in astrocytes in addition to its role in activation [58]. However, the present study indicates that IL-1 $\beta$ release is not necessary for IL- 6 release by the P2X7 receptor in RPE cells.

\subsection{Physiological Relevance}

The physiological relevance of P2X7 receptor-mediated IL-6 release from RPE cells depends on the conditions leading to stimulation of the receptor in addition to the effects of IL-6. High concentrations of ATP are necessary for endogenous receptor activation [59]. Localized release of ATP from conduits such as pannexin channels can provide sufficient ATP for autocrine stimulation of adjacent P2X7 receptors [60]. Within the retina and RPE, pathways for regulating levels of ATP are tightly controlled [46,61,62]. ATP release from RPE cells occurs following stimulation of the NMDA receptor for glutamate [63], activation of the CFTR channel [64], and from the ATP store within lysosomes following stimulation of the TLR3 receptor [65]. Whether these pathways will generate sufficient ATP to stimulate the P2X7 receptor in the tight subretinal space in vivo is unknown. However, NTPDase1, a marker of extracellular ATP levels [66], was elevated in the RPE/choroid of the $\mathrm{ABCA} 4^{-/-}$mouse model of retinal degeneration [28], consistent with increased extracellular ATP levels under chronic diseased conditions. RPE cells from $\mathrm{ABCA4} 4^{-/}$mice also express increased levels of the P2X7 receptor [28], and data in Figure 6 indicate these cells release more IL- 6 than control. Whether this contributes to the pathogenesis involved in Stargardt's Disease remains to be determined.

The consequences of IL- 6 release are expected to be complex; while IL-6 is frequently considered a "pro-inflammatory" cytokine, it can be both protective and pathological [15], with the presence of both membrane bound and soluble receptors for IL-6 influencing the outcome [67]. Classical signaling of IL-6 involves binding to the IL-6 receptor, leading to interaction of gp130 activation of Jak/Stat pathways and proinflammatory consequences. The trans-signaling pathway involves IL-6 first binding to a soluble IL-6 receptor, which in turn binds to membrane bound gp130, with trans-signaling associated with regenerative or anti-inflammatory signaling [68]. IL-6 was associated with photoreceptor protection in a model of retinal detachment, [69], and IL-6 can protect retinal ganglion cells [70,71]. However, IL-6 has recently been associated with epithelial to mesenchymal transition (EMT) [72,73], and type 2 EMT is recognized in the RPE pathology associated with AMD [74-76]. Whether increased IL-6 release following P2X7 receptor stimulation actually contributes to EMT in RPE cells is a subject of future investigation. 


\section{Conclusions}

These data indicate that stimulation of the P2X7 receptor leads to the release of cytokine IL-6 from $\mathrm{RPE}$ cells through a process involving $\mathrm{Ca}^{2+}$ influx. This release of IL-6 may increase inflammatory or protective signaling in RPE cells under conditions where extracellular ATP levels rise.

Author Contributions: Conceptualization-C.H.M.; Methodology-S.G., X.S., W.L.; Investigation-S.G., X.S., W.L., K.E.C.; Resources-J.A.M., W.Y.; Writing—Original Draft Preparation, C.H.M.; Writing-Review and Editing, C.H.M., W.L., J.M.B., W.L. All authors have read and agreed to the published version of the manuscript.

Funding: This work was supported by grants R01-EY013434, R01-EY015537 and core grant P30-EY001583 (C.H.M.), R01-DK117884 (J.M.B.), TL1-TR001880 (K.E.C.), T32-EY007035 (K.E.C.), The Jody Sack Fund (W.L.), Research to Prevent Blindness Unrestricted Grant Funds to Scheie Eye Institute (J.A.M.), F.M. Kirby Foundation, and The Paul and Evanina Bell Mackall Foundation Trust for their support The Center for Advanced Retinal and Ocular Therapeutics (CAROT, J.A.M.), The Foundation for Fighting Blindness (J.A.M.), and Penn Institute for Regenerative Medicine funding support to the iPSC Core and NIH grant U01TR001810 to support sharing of iPSC lines (W.Y.).

Acknowledgments: The authors would like to thank Thor Eysteinsson, Jason Lim and Leigh-Anne Tu for work on earlier versions of this work and Cagla Espinoza for help with the lamivudine. Some of this work has been previously presented in abstract form.

Conflicts of Interest: The authors declare no conflict of interest. The funders had no role in the design of the study; in the collection, analyses, or interpretation of data; in the writing of the manuscript, or in the decision to publish the results.

\section{References}

1. Peeters, P.M.; Wouters, E.F.; Reynaert, N.L. Immune homeostasis in epithelial cells: Evidence and role of inflammasome signaling reviewed. J. Immunol. Res. 2015, 828264. [CrossRef] [PubMed]

2. Glaser, L.; Coulter, P.J.; Shields, M.; Touzelet, O.; Power, U.F.; Broadbent, L. Airway epithelial derived cytokines and chemokines and their role in the immune response to respiratory syncytial virus infection. Pathogens 2019, 8, 8030106. [CrossRef] [PubMed]

3. Ferrari, D.; Pizzirani, C.; Adinolfi, E.; Lemoli, R.M.; Curti, A.; Idzko, M.; Panther, E.; Di Virgilio, F. The P2X7 receptor: A key player in IL-1 processing and release. J. Immunol. 2006, 176, 3877-3883. [CrossRef] [PubMed]

4. Savio, L.E.B.; de Andrade Mello, P.; da Silva, C.G.; Coutinho-Silva, R. The P2X7 receptor in inflammatory diseases: Angel or demon? Front. Pharmacol. 2018, 9, 52. [CrossRef] [PubMed]

5. Dinarello, C.A.; Simon, A.; van der Meer, J.W. Treating inflammation by blocking interleukin-1 in a broad spectrum of diseases. Nat. Rev. Drug Discov. 2012, 11, 633-652. [CrossRef]

6. Kelley, N.; Jeltema, D.; Duan, Y.; He, Y. The NLRP3 inflammasome: An overview of mechanisms of activation and regulation. Int. J. Mol. Sci. 2019, 20, 3328. [CrossRef]

7. Wu, L.; Zhou, C.; Wu, J.; Chen, S.; Tian, Z.; Du, Q. Corticosterone inhibits LPS-induced NLRP3 inflammasome priming in macrophages by suppressing xanthine oxidase. Mediat. Inflamm. 2020, 2020, 6959741. [CrossRef]

8. Lakkaraju, A. Endo-lysosome function in the retinal pigment epithelium in health and disease. Adv. Exp. Med. Biol. 2012, 723, 723-729. [CrossRef]

9. Sparrow, J.R.; Hicks, D.; Hamel, C.P. The retinal pigment epithelium in health and disease. Curr. Mol. Med. 2010, 10, 802-823. [CrossRef]

10. Detrick, B.; Hooks, J.J. The RPE cell and the immune system. In Retinal Pigment Epithelium in Health and Disease; Klettner, A.K., Dithmar, S., Eds.; Springer International Publishing: Cham, Switzerland, 2020; pp. 101-114.

11. Tarallo, V.; Hirano, Y.; Gelfand, B.D.; Dridi, S.; Kerur, N.; Kim, Y.; Cho, W.G.; Kaneko, H.; Fowler, B.J.; Bogdanovich, S.; et al. DICER1 loss and Alu RNA induce age-related macular degeneration via the NLRP3 inflammasome and MyD88. Cell 2012, 149, 847-859. [CrossRef]

12. Doyle, S.L.; Ozaki, E.; Brennan, K.; Humphries, M.M.; Mulfaul, K.; Keaney, J.; Kenna, P.F.; Maminishkis, A.; Kiang, A.S.; Saunders, S.P.; et al. IL-18 attenuates experimental choroidal neovascularization as a potential therapy for wet age-related macular degeneration. Sci. Transl. Med. 2014, 6, 230ra44. [CrossRef] [PubMed]

13. Gao, J.; Cui, J.Z.; To, E.; Cao, S.; Matsubara, J.A. Evidence for the activation of pyroptotic and apoptotic pathways in RPE cells associated with NLRP3 inflammasome in the rodent eye. J. Neuroinflamm. 2018, 15, 15. [CrossRef] [PubMed] 
14. Tseng, W.A.; Thein, T.; Kinnunen, K.; Lashkari, K.; Gregory, M.S.; D'Amore, P.A.; Ksander, B.R. NLRP3 inflammasome activation in retinal pigment epithelial cells by lysosomal destabilization: Implications for age-related macular degeneration. Investig. Ophthalmol. Vis. Sci. 2013, 54, 110-120. [CrossRef] [PubMed]

15. Spooren, A.; Kolmus, K.; Laureys, G.; Clinckers, R.; De Keyser, J.; Haegeman, G.; Gerlo, S. Interleukin-6, a mental cytokine. Brain Res. Rev. 2011, 67, 157-183. [CrossRef]

16. Sato, K.; Takeda, A.; Hasegawa, E.; Jo, Y.-J.; Arima, M.; Oshima, Y.; Ryoji, Y.; Nakazawa, T.; Yuzawa, M.; Nakashizuka, H.; et al. Interleukin-6 plays a crucial role in the development of subretinal fibrosis in a mouse model. Immunol. Med. 2018, 41, 23-29. [CrossRef] [PubMed]

17. Lu, W.; Albalawi, F.; Beckel, J.M.; Lim, J.C.; Laties, A.M.; Mitchell, C.H. The P2X7 receptor links mechanical strain to cytokine IL-6 up-regulation and release in neurons and astrocytes. J. Neurochem. 2017, 141, 436-448. [CrossRef] [PubMed]

18. Guha, S.; Baltazar, G.C.; Tu, L.A.; Liu, J.; Lim, J.C.; Lu, W.; Argall, A.; Boesze-Battaglia, K.; Laties, A.M.; Mitchell, C.H. Stimulation of the D5 dopamine receptor acidifies the lysosomal $\mathrm{pH}$ of retinal pigmented epithelial cells and decreases accumulation of autofluorescent photoreceptor debris. J. Neurochem. 2012, 122, 823-833. [CrossRef]

19. Maguire, J.A.; Gagne, A.L.; Jobaliya, C.D.; Gandre-Babbe, S.; Gadue, P.; French, D.L. Generation of human control iPS cell line CHOPWT10 from healthy adult peripheral blood mononuclear cells. Stem Cell Res. 2016, 16, 338-341. [CrossRef]

20. Pashos, E.E.; Park, Y.; Wang, X.; Raghavan, A.; Yang, W.; Abbey, D.; Peters, D.T.; Arbelaez, J.; Hernandez, M.; Kuperwasser, N.; et al. Large, diverse population cohorts of hiPSCs and derived hepatocyte-like cells reveal functional genetic variation at blood lipid-associated loci. Cell Stem Cell 2017, 20, 558-570.e10. [CrossRef]

21. Duong, T.T.; Vasireddy, V.; Ramachandran, P.; Herrera, P.S.; Leo, L.; Merkel, C.; Bennett, J.; Mills, J.A. Use of induced pluripotent stem cell models to probe the pathogenesis of Choroideremia and to develop a potential treatment. Stem Cell Res. 2018, 27, 140-150. [CrossRef]

22. Lu, W.; Gómez, N.M.; Lim, J.C.; Guha, S.; Campagno, K.E.; McCaughey, S.A.; Laties, A.M.; Carlsson, L.G.; Mitchell, C.H. The P2Y12 receptor antagonist ticagrelor reduces lysosomal $\mathrm{pH}$ and autofluorescence in retinal pigmented epithelial cells from the ABCA4-/- mouse model of retinal degeneration. Front. Pharmacol. Exp. Pharmacol. Drug Discov. 2018, 9, 242. [CrossRef] [PubMed]

23. Virginio, C.; Church, D.; North, R.A.; Surprenant, A. Effects of divalent cations, protons and calmidazolium at the rat P2X7 receptor. Neuropharmacology 1997, 36, 1285-1294. [CrossRef]

24. Gómez, N.M.; Lu, W.; Lim, J.C.; Kiselyov, K.; Campagno, K.E.; Grishchuk, Y.; Slaugenhaupt, S.A.; Pfeffer, B.A.; Fliesler, S.J.; Mitchell, C.H. Robust lysosomal calcium signaling through channel TRPML1 is impaired by lysosomal lipid accumulation. FASEB J. 2017, 32, 782-794. [CrossRef] [PubMed]

25. Uehara, F.; Yasumura, D.; LaVail, M.M. Rod- and cone-associated interphotoreceptor matrix in the rat retina. Differences in light-evoked distributional changes. Investig. Ophthalmol. Vis. Sci. 1991, 32, $285-292$.

26. Samuel, W.; Jaworski, C.; Postnikova, O.; Krishnan Kutty, R.; Duncan, T.; Tan, L.X.; Poliakov, E.; Lakkaraju, A.; Redmond, T. Appropriately differentiated ARPE-19 cells regain phenotype and gene expression profiles similar to those of native RPE cells. Mol. Vis. 2017, 23, 60-89.

27. Strauss, O. The Retinal pigment epithelium in visual function. Physiol. Rev. 2005, 85, 845-881. [CrossRef]

28. Guha, S.; Baltazar, G.C.; Coffey, E.E.; Tu, L.-A.; Lim, J.C.; Beckel, J.M.; Eysteinsson, T.; Lu, W.; O'Brien-Jenkins, A.; Patel, S.; et al. Lysosomal alkalinization, lipid oxidation, impaired autophagy and reduced phagosome clearance triggered by P2X7 receptor activation in retinal pigmented epithelial cells. FASEB J. 2013, 27, 4500-4509. [CrossRef]

29. Lehmann, G.L.; Benedicto, I.; Philp, N.J.; Rodriguez-Boulan, E. Plasma membrane protein polarity and trafficking in RPE cells: Past, present and future. Exp. Eye Res. 2014, 126, 5-15. [CrossRef]

30. Dutot, M.; Liang, H.; Pauloin, T.; Brignole-Baudouin, F.; Baudouin, C.; Warnet, J.M.; Rat, P. Effects of toxic cellular stresses and divalent cations on the human P2X7 cell death receptor. Mol. Vis. 2008, 14, 889-897.

31. Yang, D.; Elner, S.G.; Clark, A.J.; Hughes, B.A.; Petty, H.R.; Elner, V.M. Activation of P2X receptors induces apoptosis in human retinal pigment epithelium. Investig. Ophthalmol. Vis. Sci. 2011, 52, 1522-1530. [CrossRef]

32. Yang, D. Targeting the P2X7 receptor in age-related macular degeneration. Vision 2017, 1, 11. [CrossRef]

33. Vigne, P.; Hechler, B.; Gachet, C.; Breittmayer, J.P.; Frelin, C. Benzoyl ATP is an antagonist of rat and human P2Y1 receptors and of platelet aggregation. Biochem. Biophys. Res. Commun. 1999, 256, 94-97. [CrossRef] [PubMed] 
34. Allsopp, R.C.; El Ajouz, S.; Schmid, R.; Evans, R.J. Cysteine scanning mutagenesis (residues Glu52-Gly96) of the human P2X1 receptor for ATP: Mapping agonist binding and channel gating. J. Biol. Chem. 2011, 286, 29207-29217. [CrossRef]

35. Syed, N.-I.-H.; Kennedy, C. Pharmacology of P2X receptors. Wiley Interdiscip. Rev. Membr. Transp. Signal. 2012, 1, 16-30. [CrossRef]

36. Ohtomo, K.; Shatos, M.A.; Vrouvlianis, J.; Li, D.; Hodges, R.R.; Dartt, D.A. Increase of intracellular Ca ${ }^{2+}$ by purinergic receptors in cultured rat lacrimal gland myoepithelial cells. Investig. Ophthalmol. Vis. Sci. 2011, 52, 9503-9515. [CrossRef]

37. Michel, A.D.; Chambers, L.J.; Walter, D.S. Negative and positive allosteric modulators of the P2X(7) receptor. Br. J. Pharmacol. 2008, 153, 737-750. [CrossRef] [PubMed]

38. Honore, P.; Donnelly-Roberts, D.; Namovic, M.; Zhong, C.; Wade, C.; Chandran, P.; Zhu, C.; Carroll, W.; Perez-Medrano, A.; Iwakura, Y.; et al. The antihyperalgesic activity of a selective P2X7 receptor antagonist, A-839977, is lost in IL-1alphabeta knockout mice. Behav. Brain Res. 2009, 204, 77-81. [CrossRef]

39. Mizutani, T.; Fowler, B.J.; Kim, Y.; Yasuma, R.; Krueger, L.A.; Gelfand, B.D.; Ambati, J. Nucleoside reverse transcriptase inhibitors suppress laser-induced choroidal neovascularization in mice. Investig. Ophthalmol. Vis. Sci. 2015, 56, 7122-7129. [CrossRef]

40. Liang, X.; Samways, D.S.K.; Cox, J.; Egan, T.M. Ca $\left({ }^{2+}\right)$ flux through splice variants of the ATP-gated ionotropic receptor P2X7 is regulated by its cytoplasmic N terminus. J. Biol. Chem. 2019, 294, 12521-12533. [CrossRef]

41. Cahill, C.M.; Rogers, J.T. Interleukin (IL) 1beta induction of IL-6 is mediated by a novel phosphatidylinositol 3-kinase-dependent AKT/IkappaB kinase alpha pathway targeting activator protein-1. J. Biol. Chem. 2008, 283, 25900-25912. [CrossRef]

42. Elner, V.M.; Scales, W.; Elner, S.G.; Danforth, J.; Kunkel, S.L.; Strieter, R.M. Interleukin-6 (IL-6) gene expression and secretion by cytokine-stimulated human retinal pigment epithelial cells. Exp. Eye Res. 1992, 54, 361-368. [CrossRef]

43. Weng, J.; Mata, N.L.; Azarian, S.M.; Tzekov, R.T.; Birch, D.G.; Travis, G.H. Insights into the function of Rim protein in photoreceptors and etiology of Stargardt's disease from the phenotype in abcr knockout mice. Cell 1999, 98, 13-23. [CrossRef]

44. Steinberg, R.H.; Wood, I. Pigment epithelial cell ensheathment of cone outer segments in the retina of the domestic cat. Proc. R Soc. Lond. B Biol. Sci. 1974, 187, 461-478. [CrossRef] [PubMed]

45. Curcio, C.A.; Johnson, M. Chapter 20-Structure, Function, and Pathology of Bruch's Membrane. In Retina, 5th ed.; Ryan, S.J., Sadda, S.R., Hinton, D.R., Schachat, A.P., Sadda, S.R., Wilkinson, C.P., Wiedemann, P., Schachat, A.P., Eds.; W.B. Saunders: London, UK, 2013; pp. 465-481.

46. Mitchell, C.H.; Reigada, D. Purinergic signalling in the subretinal space: A role in the communication between the retina and the RPE. Purinergic Signal. 2008, 4, 101-107. [CrossRef]

47. Linden, J.; Koch-Nolte, F.; Dahl, G. Purine release, metabolism, and signaling in the inflammatory response. Annu. Rev. Immunol. 2019, 37, 325-347. [CrossRef]

48. Kerur, N.; Hirano, Y.; Tarallo, V.; Fowler, B.J.; Bastos-Carvalho, A.; Yasuma, T.; Yasuma, R.; Kim, Y.; Hinton, D.R.; Kirschning, C.J.; et al. TLR-independent and P2X7-dependent signaling mediate Alu RNA-induced NLRP3 inflammasome activation in geographic atrophy. Investig. Ophthalmol. Vis. Sci. 2013, 54, 7395-7401. [CrossRef]

49. Di Virgilio, F.; Giuliani, A.L.; Vultaggio-Poma, V.; Falzoni, S.; Sarti, A.C. Non-nucleotide agonists triggering P2X7 receptor activation and pore formation. Front. Pharmacol. 2018, 9, 39. [CrossRef]

50. North, R.A.; Surprenant, A. Pharmacology of cloned P2X receptors. Annu. Rev. Pharmacol. Toxicol. 2000, 40, 563-580. [CrossRef]

51. Donnelly-Roberts, D.L.; Namovic, M.T.; Han, P.; Jarvis, M.F. Mammalian P2X7 receptor pharmacology: Comparison of recombinant mouse, rat and human P2X7 receptors. Br. J. Pharmacol. 2009, 157, 1203-1214. [CrossRef]

52. Liang, X.; Samways, D.S.; Wolf, K.; Bowles, E.A.; Richards, J.P.; Bruno, J.; Dutertre, S.; DiPaolo, R.J.; Egan, T.M. Quantifying $\mathrm{Ca}^{2+}$ current and permeability in ATP-gated P2X7 receptors. J. Biol. Chem. 2015, 290, 7930-7942. [CrossRef]

53. Stanley, A.C.; Lacy, P. Pathways for cytokine secretion. Physiology 2010, 25, 218-229. [CrossRef] [PubMed]

54. Murray, R.Z.; Stow, J.L. Cytokine secretion in macrophages: SNAREs, Rabs, and membrane trafficking. Front. Immunol. 2014, 5, 538. [CrossRef] [PubMed] 
55. Uhl, P.B.; Szober, C.M.; Amann, B.; Alge-Priglinger, C.; Ueffing, M.; Hauck, S.M.; Deeg, C.A. In situ cell surface proteomics reveals differentially expressed membrane proteins in retinal pigment epithelial cells during autoimmune uveitis. J. Proteom. 2014, 109, 50-62. [CrossRef] [PubMed]

56. Munoz, F.M.; Patel, P.A.; Gao, X.; Mei, Y.; Xia, J.; Gilels, S.; Hu, H. Reactive oxygen species play a role in P2X7 receptor-mediated IL-6 production in spinal astrocytes. Purinergic Signal. 2020, 16, 97-107. [CrossRef] [PubMed]

57. Shieh, C.H.; Heinrich, A.; Serchov, T.; van Calker, D.; Biber, K. P2X7-dependent, but differentially regulated release of IL-6, CCL2, and TNF- $\alpha$ in cultured mouse microglia. Glia 2014, 62, 592-607. [CrossRef]

58. Albalawi, F.; Lu, W.; Beckel, J.M.; Lim, J.C.; McCaughey, S.A.; Mitchell, C.H. The P2X7 receptor primes IL-1 $\beta$ and the NLRP3 inflammasome in astrocytes exposed to mechanical strain. Front. Cell Neurosci. 2017, 11, 227. [CrossRef]

59. Khakh, B.S.; Burnstock, G.; Kennedy, C.; King, B.F.; North, R.A.; Seguela, P.; Voigt, M.; Humphrey, P.P. International union of pharmacology. XXIV. Current status of the nomenclature and properties of P2X receptors and their subunits. Pharmacol. Rev. 2001, 53, 107-118.

60. Dahl, G. ATP release through pannexon channels. Philos. Trans. R Soc. Lond. B Biol. Sci. 2015, 370, 20140191. [CrossRef]

61. Sanderson, J.; Dartt, D.A.; Trinkaus-Randall, V.; Pintor, J.; Civan, M.M.; Delamere, N.A.; Fletcher, E.L.; Salt, T.E.; Grosche, A.; Mitchell, C.H. Purines in the eye: Recent evidence for the physiological and pathological role of purines in the RPE, retinal neurons, astrocytes, Muller cells, lens, trabecular meshwork, cornea and lacrimal gland. Exp. Eye Res. 2014, 127, 270-279. [CrossRef]

62. Ventura, A.L.M.; dos Santos-Rodrigues, A.; Mitchell, C.H.; Faillace, M.P. Purinergic signaling in the retina: From development to disease. Brain Res. Bull. 2019, 151, 92-108. [CrossRef]

63. Reigada, D.; Lu, W.; Mitchell, C.H. Glutamate acts at NMDA receptors on fresh bovine and on cultured human retinal pigment epithelial cells to trigger release of ATP. J. Physiol. 2006, 575 Pt 3, 707-720. [CrossRef]

64. Reigada, D.; Mitchell, C.H. Release of ATP from retinal pigment epithelial cells involves both CFTR and vesicular transport. Am. J. Physiol. Cell Physiol. 2005, 288, C132-C140. [CrossRef] [PubMed]

65. Beckel, J.M.; Gomez, N.M.; Lu, W.; Campagno, K.E.; Nabet, B.; Albalawi, F.; Lim, J.C.; Boesze-Battaglia, K.; Mitchell, C.H. Stimulation of TLR3 triggers release of lysosomal ATP in astrocytes and epithelial cells that requires TRPML1 channels. Sci. Rep. 2018, 8, 5726. [CrossRef] [PubMed]

66. Lu, W.; Reigada, D.; Sevigny, J.; Mitchell, C.H. Stimulation of the P2Y1 receptor up-regulates nucleoside-triphosphate diphosphohydrolase-1 in human retinal pigment epithelial cells. J. Pharmacol. Exp. Ther. 2007, 323, 157-164. [CrossRef] [PubMed]

67. Rose-John, S. Interleukin-6 Family Cytokines. Cold Spring Harb. Perspect Biol. 2018, 10. [CrossRef] [PubMed]

68. Rose-John, S. IL-6 trans-signaling via the soluble IL-6 receptor: Importance for the pro-inflammatory activities of IL-6. Int. J. Biol. Sci. 2012, 8, 1237-1247. [CrossRef] [PubMed]

69. Chong, D.Y.; Boehlke, C.S.; Zheng, Q.D.; Zhang, L.; Han, Y.; Zacks, D.N. Interleukin-6 as a photoreceptor neuroprotectant in an experimental model of retinal detachment. Investig. Ophthalmol. Vis. Sci. 2008, 49, 3193-3200. [CrossRef]

70. Echevarria, F.D.; Formichella, C.R.; Sappington, R.M. Interleukin-6 deficiency attenuates retinal ganglion cell axonopathy and glaucoma-related vision loss. Front. Neurosci. 2017, 11, 318. [CrossRef]

71. Echevarria, F.D.; Rickman, A.E.; Sappington, R.M. Interleukin-6: A constitutive modulator of glycoprotein 130, neuroinflammatory and cell survival signaling in retina. J. Clin. Cell Immunol. 2016, 7. [CrossRef]

72. Zhou, J.; Zhang, C.; Pan, J.; Chen, L.; Qi, S.T. Interleukin6 induces an epithelialmesenchymal transition phenotype in human adamantinomatous craniopharyngioma cells and promotes tumor cell migration. Mol. Med. Rep. 2017, 15, 4123-4131. [CrossRef]

73. Ebbing, E.A.; van der Zalm, A.P.; Steins, A.; Creemers, A.; Hermsen, S.; Rentenaar, R.; Klein, M.; Waasdorp, C.; Hooijer, G.K.J.; Meijer, S.L.; et al. Stromal-derived interleukin 6 drives epithelial-to-mesenchymal transition and therapy resistance in esophageal adenocarcinoma. Proc. Natl. Acad. Sci. USA 2019, 116, 2237-2242. [CrossRef]

74. Kimura, K.; Orita, T.; Liu, Y.; Yang, Y.; Tokuda, K.; Kurakazu, T.; Noda, T.; Yanai, R.; Morishige, N.; Takeda, A.; et al. Attenuation of EMT in RPE cells and subretinal fibrosis by an RAR- $\gamma$ agonist. J. Mol. Med. 2015, 93, 749-758. [CrossRef] 
75. Radeke, M.J.; Radeke, C.M.; Shih, Y.H.; Hu, J.; Bok, D.; Johnson, L.V.; Coffey, P.J. Restoration of mesenchymal retinal pigmented epithelial cells by TGFbeta pathway inhibitors: Implications for age-related macular degeneration. Genome Med. 2015, 7, 58. [CrossRef]

76. Ghosh, S.; Shang, P.; Terasaki, H.; Stepicheva, N.; Hose, S.; Yazdankhah, M.; Weiss, J.; Sakamoto, T.; Bhutto, I.A.; Xia, S.; et al. A Role for betaA3/A1-Crystallin in Type 2 EMT of RPE Cells Occurring in Dry Age-Related Macular Degeneration. Investig. Ophthalmol. Vis. Sci. 2018, 59, AMD104-AMD113. [CrossRef]

Publisher's Note: MDPI stays neutral with regard to jurisdictional claims in published maps and institutional affiliations.

(C) 2020 by the authors. Licensee MDPI, Basel, Switzerland. This article is an open access article distributed under the terms and conditions of the Creative Commons Attribution (CC BY) license (http://creativecommons.org/licenses/by/4.0/). 